\title{
SOIL ATTRIBUTES AND C AND N VARIATION IN HISTOSOLS UNDER DIFFERENT AGRICULTURAL USAGES IN THE STATE OF RIO DE JANEIRO, BRAZIL
}

\author{
ATRIBUTOS EDÁFICOS E VARIAÇÃO DE C E N EM ORGANOSSOLOS SOB \\ DIFERENTES USOS AGRÍCOLAS NO ESTADO DO RIO DE JANEIRO, BRASIL
}

\section{Paula Fernanda Chaves SOARES ${ }^{1}$; Fernando ZUCHELLO²; Lúcia Helena Cunha dos ANJOS ${ }^{3}$; Marcos Gervasio PEREIRA ${ }^{3}$; Ana Paula Pessim de OLIVEIRA ${ }^{4}$}

1. Pós-Doutoranda CPGA-CS, Universidade Federal Rural do Rio de Janeiro - UFRRJ, Seropédica, RJ, Brasil. pfernanda07@gmail.com; 2. Professor, Doutor, Instituto Federal Catarinense - Campus Concórdia, Concórdia, SC; 3. Professor, Doutor, Departamento de Solos, Universidade Federal Rural do Rio de Janeiro - UFRRJ, Seropédica, RJ, Brasil; 4. Pós-Doutoranda PPGCTIA, Universidade Federal Rural do Rio de Janeiro - UFRRJ, Seropédica, RJ, Brasil.

\begin{abstract}
Histosols are a natural reservoir of $\mathrm{C}$ in the soil, and their drainage followed by other farming practices leads to subsidence and soil organic matter transformations. The objective of this study was to evaluate the influence of use and management of Histosols, by means of: characterizing chemical and physical properties, and the content of SOM and humic fractions; and quantifying $\mathrm{C}$ and $\mathrm{N}$ stocks. In addition, to obtain preliminary data on greenhouse gas emissions $\left(\mathrm{CO}_{2}, \mathrm{~N}_{2} \mathrm{O}\right)$ in Histosol areas with different agricultural practices. Three areas were selected with similar soil and environment, two in Macaé municipality, under pasture, and with bean annual crop rotation, and the third in Santa Cruz, Rio de Janeiro city, cultivated with cassava (Manihot esculenta). The attributes evaluated were: physical - bulk density (BD), particle density (Dp), organic matter density (OMD), mineral matter (MM), mineral residue (MR), aggregate stability; and chemical - $\mathrm{pH}$, exchangeable cations, soil organic matter (SOM), carbon in the humin (HUM-C), humic acid (HAF-C) and fulvic acid (FAF-C) fractions; stocks of $\mathrm{C}$ and $\mathrm{N}$; and flux of $\mathrm{CO}_{2}$ and $\mathrm{N}_{2} \mathrm{O}$. In general, the area cultivated with cassava had the highest values for exchangeable cations, as a result of fertilizer and soil management practices. The cassava site showed the highest values of BD and Dp; total volume of pores; MM, MR and OMD and higher degree of transformation of SOM; indicating higher alteration of Histosols properties under this usage. In all sites, the $\mathrm{C}$ levels indicated dominance of humin fraction. The SOM and $\mathrm{C}$ and $\mathrm{N}$ stocks were highest in the pasture, indicating preservation of organic matter, with values from 115.92 to $99.35 \mathrm{Mg} \mathrm{ha}^{-1}$ of C e 8.35 to $4.45 \mathrm{Mg} \mathrm{ha}^{-1}$ for N. The values of $\mathrm{CO}_{2}-\mathrm{C}$ flux were within the range proposed by the IPCC, where the highest emission was $0.09 \mathrm{Mg} \mathrm{CO}_{2}$ ha $^{-1}$ day $^{-1}$ in the pasture site. The values of $\mathrm{N}_{2} \mathrm{O}-\mathrm{N}$ flux were lower than proposed by the IPCC, with the highest value $\left(270 \mathrm{~g} \mathrm{~N} \mathrm{~N}_{2} \mathrm{O}-\mathrm{N}\right.$ $\mathrm{m}^{-2}$ day $^{-1}$ ) in the area under beans (crop rotation). In general, the multivariate analyses discriminated the sites and the pasture was the usage that least affected the Histosols properties.
\end{abstract}

KEYWORDS: Humic Substances. $\mathrm{C}$ and $\mathrm{N}$ stocks. $\mathrm{CO}_{2}$ and $\mathrm{N}_{2} \mathrm{O}$ emissions.

\section{INTRODUCTION}

The use and occupation of Histosols should be planned rationally in order to avoid negative environmental impacts on natural resources (MOURA et al., 2013; NOGUEIRA et al., 2012). They are important to environmental changes, and it is estimated that to a depth of one meter, in global terms, the soil contains $2200 \mathrm{Pg} \mathrm{C}$, corresponding to about four times the $\mathrm{C}$ in vegetation $(560 \mathrm{Pg})$ and three times $\mathrm{C}$ in the atmosphere $(750 \mathrm{Pg})$. The $\mathrm{C}$ stored in soil is composed of organic C (1500 Pg C) and mineral C (700 Pg C) (BATJES, 1996). However, the soil organic matter is easily decomposed through cropping (CIPRIANO-SILVA et al., 2014) thus aggravating the release of gases such as $\mathrm{CO}_{2}$ (CERRI et al., 2007).
When drainage for agriculture is implemented the subsidence process of Histosols starts and the content of soil organic matter changes rapidly (EBELING et al., 2013). In Histosols the mineralization of organic matter and release of gases can be greater than in other soils, and it is enhanced by drainage and cropping. In flooded areas, SOM decomposes anaerobically and produces compounds like $\mathrm{CH}_{4}$. In Histosols, drainage promotes aerobic decomposition of soil organic matter (SOM), generating $\mathrm{CO}_{2}$, which is later released by diffusion to the atmosphere. The $\mathrm{N}_{2} \mathrm{O}$ is the second most abundant form of $\mathrm{N}$ in the atmosphere and is highly stable, with residence time of approximatley 110 to 150 years (BATJES et al., 1996). In comparison with $\mathrm{CO}_{2}, \mathrm{~N}_{2} \mathrm{O}$ has 298 times the warming potential, while $\mathrm{CH}_{4}$ has 25 times as much (IPCC, 2007; YAO et al., 2012). 
Histosols are different from other soils, and they are defined in the Brazilian Soil Classification System (SiBCS) (EMBRAPA, 2013) as less developed soils with high organic carbon $\left(\geq 80 \mathrm{~g} \mathrm{~kg}^{-}\right.$ $\left.{ }^{1}\right)$. Among their distinctive edaphic characteristics are the dark colors and high moisture retention, susceptibility to subsidence, acidity and cation exchange capacity (CEC), as well as presence of plant matterial at different stages of decomposition.

In contrast, the increase in the SOM stock is slow and needs adequate soil management, particularly in tropical regions where decomposition is faster due to the higher biological activity (SIX et al., 2002). In Serra de Espinhaço Meridional region of Minas Gerais, Silva et al. (2007) found Histosols acidic and with high concentrations of exchangeable $\mathrm{Al}^{3+}$ and potential acidity; with high CEC as a function of depotronation or protonation of carboxyl and phenyl radicals.

In Histosols, the properties and characteristics of the organic matter determine the rate of mineralization and emissions of $\mathrm{C}$ and $\mathrm{N}$ to the atmosphere in the form of gases. The objective of this study was to evaluate the influence of use and management of Histosols, by means of: characterizing chemical and physical properties, and the content of SOM and humic fractions; and quantifying $\mathrm{C}$ and $\mathrm{N}$ stocks. In addition, to obtain preliminary data on greenhouse gas emissions $\left(\mathrm{CO}_{2}\right.$, $\mathrm{N}_{2} \mathrm{O}$ ) in Histosol areas with different agricultural practices.

\section{MATERIAL AND METHODS}

\section{Location and Characterization of the Areas and Soil Sampling}

The study was conducted in three areas with soils classified as Histosols, according to the SiBCS (EMBRAPA, 2013), in floodplain regions of Rio de Janeiro State and with different tillages and cover crops. The first area (1), in the municipality of Macaé, has been cultivated with mixed pasture consisting of Brachiaria brizantha and leguminous, for beef cattle production. The water table level is controlled by channels along the Macaé and São Pedro rivers, at a depth of approximately $60 \mathrm{~cm}$. The second area (2) is adjacent to the first; this area is planted with corn (Zea mays), rice (Oryza sativa), and beans (Phaseolus vulgaris) for seed production, in a crop rotation system. The cultivation practices are by conventional tillage, consisting of plowing and harrowing the surface layers. The drainage channels are deeper (approximately $1.5 \mathrm{~m}$ ) and closer than in the first area. The third area (3), in Santa Cruz district, in the western part of Rio de
Janeiro city, has been planted with cassava (Manihot esculenta) since the 1980s. The soil is mechanized and the cassava is planted in raised beds about 30 $\mathrm{cm}$ high, and dolomitic lime was applied during the period of cultivation. The drainage channels are 80 $\mathrm{cm}$ deep. The third area has been cultivated for the longest period, as part of a settlement project starting in the 1940s, which included the macrodrainage of the region.

The soil was sampled in 2009 and 2010, in areas 1 and 2 in April and in area 3 in May. In each location there were three sites selected for trenching, and in each trench samples were collected at depth intervals of 0-10 and $10-20 \mathrm{~cm}$.

\section{Analytic Characterization}

The air dry soil samples were analyzed for $\mathrm{Ca}, \mathrm{Mg}, \mathrm{Na}, \mathrm{K}, \mathrm{Al}, \mathrm{H}+\mathrm{Al}, \mathrm{pH}$ and $\mathrm{C}$ according to Embrapa (1997), and the $\mathrm{N}$ according to Tedesco et al. (1995). The $\mathrm{pH}$ was determined in a soil-liquid suspension of $1: 2.5$, in water, $\mathrm{CaCl}_{2} 0.01 \mathrm{~mol} \mathrm{~L}^{-1}$ and $\mathrm{KCl} 1 \mathrm{~mol} \mathrm{~L}^{-1}$. The soil total $\mathrm{C}$ and $\mathrm{N}$ contents were determined in a Tru-Spec $\mathrm{CHN}$ elemental analyzer, which was calibrated with the 'Acetanilide' standard $\left(\mathrm{C}_{8} \mathrm{H}_{9} \mathrm{NO}\right)$ part 501-053, lot 1010 (the respective values of $\mathrm{CHN}$ were $71.09 \%$, $6.71 \%$ and $10.36 \%$ ). This methodology was an adaptation of Smith \& Myung (1990).

The stocks were calculated based on the $\mathrm{C}$ and $\mathrm{N}$ amounts determined by the CHN analyzer, in the soil sections at the depths of 0-10 and 10-20 cm. The soil density values were homogeneous in the soil samples, thus the equation, without mass correlation, was used: Ss = BD.Px.X, according to Embrapa (1997); where: Ss is the total stock of carbon/nitrogen in $\mathrm{Mg} \mathrm{ha}^{-1}, \mathrm{BD}$ is the soil bulk density in $\mathrm{Mg} \mathrm{m}^{-3}, \mathrm{P}$ is the thickness in $\mathrm{cm}$, and $\mathrm{X}$ is the carbon/nitrogen concentration in $\mathrm{Mg} \mathrm{ha}^{-1}$.

The soil organic matter was determined by quantitative combustion method in a muffla furnace for $6 \mathrm{~h}$ at $600{ }^{\circ} \mathrm{C}$, according to Embrapa (2013). The soil mass lost by combustion in relation to ovendried sample corresponds to the soil organic matter (SOM). The mineral matter percent (\%MM), organic matter density (OMD) and mineral residue (MR) was calculated according to Embrapa (2013). The humic substances were chemically fractioned using the differential solubility technique based on Kononova (1966) and adapted by Benites et al. (2003). The organic $C$ was fractioned in the following: fulvic acid (FAF-C), humic acid (HAFC) and humin (HUM-C). From these values the HAF-C/FAF-C was calculated.

Measurements of $\mathrm{CO}_{2}$ and $\mathrm{N}_{2} \mathrm{O}$ emission rates from the soil were also collected in 2009 and 
2010 at the end of year. The $\mathrm{N}_{2} \mathrm{O}$ was measured according with Alves et al. (2012) and is expressed in $\mathrm{kg} \mathrm{ha}^{-1}$ year $^{-1}$. A portable infrared gas analyzer (IRGA) from PP Systems Company (2010) was used for measuring $\mathrm{CO}_{2}$. Samples were taken once a day, in the morning, at each site, for four consecutive days; there were six readings taken per day plus a reference measurement.

The soil bulk density was measured according to Embrapa (1997). The distribution of the aggregate classes was determined by sifting samples in water in a Yooder device, using sieves with mesh sizes of 2.0, 1.0, 0.5, 0.25 and $0.105 \mathrm{~mm}$, following Embrapa (1997).

\section{Statistical Analyses}

To evaluate the data, each area was considered as a treatment (identified by the coverage/crops: pasture, beans and cassava) and treated as completely randomized experimental design, with three field replicates in each area. The data were submitted to homogeneity (Bartlett) and normality (Lilliefors) tests. The data was submitted to variance analysis (ANOVA), and when significant the Tukey test $(\mathrm{p}<0.05)$ was applied. The data was compared for the areas, depths and samplings, with their interactions serving as a variation source. Multivariate analysis was also performed, using the principal components analysis (PCA) tool of the Canoco 4.5 program (VAN DEN BRINK; TER BRAAK, 1999).

\section{RESULTS AND DISCUSSION}

\section{Characterization of the Sorption Complex, pH and Organic Matter Content}

The concentrations of elements of the sorption complex were, in general, high in both sampling years (Table 1). In the first year, the values of $\mathrm{Al}^{3+}$ ranged from 1.2 to $2.7 \mathrm{cmol}_{\mathrm{c}} \mathrm{kg}^{-1}$, and there was no difference between areas or depths. $\mathrm{H}^{+}$ions predominate in the sorption complex, varying from 22.4 to $32.7(0-10 \mathrm{~cm})$ and from 23.9 to $32.1(10-20$ $\mathrm{cm}) \mathrm{cmol}_{\mathrm{c}} \mathrm{kg}^{-1}$ and the values showed differences when comparing the areas, with highest values in cassava site, followed by pasture, then beans, at both soil depths. High $\mathrm{H}^{+}$values were reported for Ebeling et al. (2008; 2011) and Silva et al. (2009), working with Histosols in floodplain and in highland environments. In 2008, Ebelimg et al. observed $\mathrm{H}^{+}$values in floodplain soils from 10 to $83,6 \mathrm{cmolc} \mathrm{kg}^{-1}$, and in highland well-drained soils from 11.9 to $83.6 \mathrm{cmolc} \mathrm{kg}^{-1}$. In 2009, Silva et al. found in highland soils $\mathrm{H}^{+}$values higher than 100 cmolc $\mathrm{kg}^{-1}$ at the depth of $10-20 \mathrm{~cm}$.
For the second year, the $\mathrm{Al}^{3+}$ levels showed differences between the areas at the depth of 10-20 $\mathrm{cm}$ (Table 1). The highest values were found in pasture and the lowest in the cassava, reflecting the management (fertilization and liming). The concentrations of $\mathrm{Al}^{3+}$ did not differ according to depths or between the years. There were no differences for $\mathrm{H}^{+}$between the treatments and depths.

$\mathrm{Ca}^{+2}$ and $\mathrm{Mg}^{+2}$ showed high values in the first sampling year, and the $\mathrm{Ca} / \mathrm{Mg}$ ratio was generally on the order of 3:1 (Table 1). The level of $\mathrm{Ca}^{+2}$ ranged from 9.3 to $19.4(0-10 \mathrm{~cm})$ and from 9.3 to $20.4(10-20 \mathrm{~cm}) \mathrm{cmol}_{\mathrm{c}} \mathrm{kg}^{-1}$ and there were differences between the areas in both depths, with the cassava and pasture having the highest values, followed by the bean site. The levels of $\mathrm{Mg}^{+}$varied from 3.5 to $6.7 \mathrm{cmol}_{\mathrm{c}} \mathrm{kg}^{-1}$ in the first year sampling at $0-10$ and $10-20 \mathrm{~cm}$ and there was no difference between areas. In the second year $\mathrm{Ca}^{+2}$ values varied from 4.4 to $9.8 \mathrm{cmol}_{\mathrm{c}} \mathrm{kg}^{-1}$ at $0-10$ and $10-20 \mathrm{~cm}$ and there was no difference between values. For $\mathrm{Mg}^{+2}$, the areas differed at the $10-20 \mathrm{~cm}$ depth, with the cassava field presenting the highest value in the second year; although there was no significant difference in values with depth or sampling years. The $\mathrm{K}$ value was relatively low and did not vary significantly with depth, in both years. The cassava is cultivated frequently with additions of fertilizer and liming, thus explaining the higher $\mathrm{Ca}^{+2}$ and $\mathrm{Mg}^{+2}$ levels in comparison to the other sites.

The $\mathrm{pH}$ values showed no variation in the first year (Table 1). The $\mathrm{pH}$ values were always higher when measured in water and lower in $\mathrm{KCl}$ solution (at least 0.8 units less than $\mathrm{pH}$ in water). These results are attributed to the effect of $\mathrm{KCl}$ solution, which in contact with the soil sample, induces exchange of cations due to the higher concentration of $\mathrm{K}^{+}$ions, releasing $\mathrm{H}^{+}$ions and $\mathrm{Al}^{3+}$ to the solution, resulting in increased acidity (EBELING et al., 2008).

In the second year, the $\mathrm{pH}$ in water showed significant differences for the sites at all depths, with higher values in the cassava, followed by beans, then pasture, in response to agricultural practices (Table 1). Similar results were observed in other regions of Brazil, with lower $\mathrm{pH}$ values in the upper layer of soils under pasture, compared to cassava and beans (MELO et al., 2010) and compared to areas with other crops (NOGUEIRA et al., 2012). According to these authors, the highest $\mathrm{pH}$ values in fruit crops are related to greater use of fertilizer and lime. The $\mathrm{pH}$ values in water are within the range reported by Ebeling et al. (2008; 2011) and Silva et al. (2009). 
Table 1. Values of the elements of the sorption complex, and $\mathrm{pH}$ with different solutions, for the three treatments, in the first and second samplings, at depths of 0-10 and $10-20 \mathrm{~cm}$

\begin{tabular}{|c|c|c|c|c|c|c|c|c|c|c|}
\hline \multirow[t]{2}{*}{ Area } & Depth & $\mathrm{Al}^{+3}$ & $\mathrm{H}^{+}$ & $\mathrm{Ca}^{+2}$ & $\mathrm{Mg}^{+2}$ & $\mathrm{~K}^{+}$ & $\mathrm{Na}^{+}$ & \multicolumn{3}{|c|}{$\mathrm{pH}$ values } \\
\hline & $(\mathrm{cm})$ & \multicolumn{6}{|c|}{$\ldots \ldots \ldots \ldots .\left(\mathrm{cmol}_{\mathrm{c}} \mathrm{kg}^{-1}\right) \ldots \ldots \ldots \ldots$} & $\mathrm{H}_{2} \mathrm{O}$ & $\mathrm{CaCl}_{2}$ & $\mathrm{KCl}$ \\
\hline & & \multicolumn{9}{|c|}{ First Sampling - 2009} \\
\hline Pasture & & 2.7Aa(a) & 27.5ABa(a) & 14.1Aba(a) & 4.9Aa(a) & $0.10 \mathrm{Aa}(\mathrm{a})$ & 0.49Aa(a) & 4.8Aa(a) & 4.2Aa(a) & 4.0Aa(a) \\
\hline Bean & $0-10$ & $1.3 \mathrm{Aa}(\mathrm{a})$ & $22.4 \mathrm{Ba}(\mathrm{a})$ & 9.3Ba(a) & 3.47Aa(a) & $0.28 \mathrm{Aa}(\mathrm{a})$ & $0.37 \mathrm{Aa}(\mathrm{a})$ & 5.0Aa(a) & 4.2Aa(a) & 4.1Aa(a) \\
\hline Cassava & & $1.2 \mathrm{Aa}(\mathrm{a})$ & 32.7Aa(a) & 19.4Aa(a) & 6.73Aab(a) & $0.66 \mathrm{Aa}(\mathrm{b})$ & $0.73 \mathrm{Aa}(\mathrm{a})$ & 4.8Aa(b) & 4.1Aa(a) & 3.9Aa(a) \\
\hline Pasture & & $1.2 \mathrm{Aa}(\mathrm{a})$ & 29.7ABa(a) & 14.9Aba(a) & 4.3Aa(a) & $0.09 \mathrm{Aa}(\mathrm{a})$ & $0.35 \mathrm{Aa}(\mathrm{a})$ & 4.7Aa(a) & 4.2Aa(a) & 3.8Aa(a) \\
\hline Bean & $10-20$ & $1.5 \mathrm{Aa}(\mathrm{a})$ & $23.9 \mathrm{Ba}(\mathrm{a})$ & $9.3 \mathrm{Ba}(\mathrm{a})$ & 3.6Aa(a) & $0.19 \mathrm{Aa}(\mathrm{a})$ & $0.38 \mathrm{Aa}(\mathrm{a})$ & $5.0 \mathrm{Aa}(\mathrm{a})$ & $4.2 \mathrm{Aa}(\mathrm{a})$ & 4.1 Aa(a) \\
\hline \multirow[t]{2}{*}{ Cassava } & & $1.8 \mathrm{Aa}(\mathrm{a})$ & 32.1Aa(a) & 20.4Aa(a) & $5.7 \mathrm{Ab}(\mathrm{a})$ & $0.20 \mathrm{Aa}(\mathrm{b})$ & $0.73 \mathrm{Aa}(\mathrm{a})$ & $4.8 \mathrm{Aa}(\mathrm{b})$ & 4.1Aa(a) & 3.9Aa(a) \\
\hline & & \multicolumn{9}{|c|}{ Second Sampling - 2010} \\
\hline Pasture & & $2.5 \mathrm{Aa}(\mathrm{a})$ & $19.5 \mathrm{Aa}(\mathrm{a})$ & 7.03Aa(a) & 2.87Aa(a) & $0.75 \mathrm{Ba}(\mathrm{a})$ & $0.54 \mathrm{Aa}(\mathrm{a})$ & 4.8Ba(a) & 4.3Aa(a) & 4.1Aa(a) \\
\hline Bean & $0-10$ & $1.6 \mathrm{Aa}(\mathrm{a})$ & 14.1Aa(a) & 4.60Aa(a) & $5.33 \mathrm{Aa}(\mathrm{a})$ & $0.98 \mathrm{Ba}(\mathrm{a})$ & $0.55 \mathrm{Aa}(\mathrm{a})$ & 5.2Aba(a) & $4.3 \mathrm{Aa}(\mathrm{a})$ & 4.3Aa(a) \\
\hline Cassava & & $0.6 \mathrm{Aa}(\mathrm{a})$ & 13.3Aa(b) & $9.83 \mathrm{Aa}(\mathrm{b})$ & 6.63Aa(a) & 4.54Aa(a) & $0.53 \mathrm{Aa}(\mathrm{a})$ & $5.5 \mathrm{Aa}(\mathrm{a})$ & 4.3Aa(a) & 4.5Aa(a) \\
\hline Pasture & & 3.7Aa(a) & 21.3Aa(a) & 4.77Aa(b) & 4.07Ba(a) & $0.68 \mathrm{Ba}(\mathrm{a})$ & $0.42 \mathrm{Aa}(\mathrm{a})$ & 4.7Ba(a) & 4.2Aa(a) & 4.0Aa(a) \\
\hline Bean & $10-20$ & $1.3 \mathrm{ABa}(\mathrm{a})$ & 13.6Aa(a) & 4.40Aa(a) & 4.70ABa(a) & $0.73 \mathrm{Ba}(\mathrm{a})$ & $0.47 \mathrm{Aa}(\mathrm{a})$ & 5.2Aba(a) & 4.4Aa(a) & 4.3Aa(a) \\
\hline Cassava & & $0.8 \mathrm{Ba}(\mathrm{a})$ & 13.6Aa(b) & $9.60 \mathrm{Aa}(\mathrm{b})$ & 8.67Aa(a) & 4.36Aa(a) & $0.66 \mathrm{Aa}(\mathrm{a})$ & $5.5 \mathrm{Aa}(\mathrm{a})$ & 4.2Aa(a) & 4.4Aa(a) \\
\hline
\end{tabular}

\# The capital letter represents the treatments at the same depth; the small letter represents the depths within the same treatment; the letters in parentheses represent the sampling year. 
The SOM content calculated from organic $\mathrm{C}$ values (EMBRAPA, 1997), varied from 142.9 to $292.3 \mathrm{~g} \mathrm{~kg}^{-1}$ in the first year and from 142.1 to 303.2 $\mathrm{g} \mathrm{kg}^{-1}$ in the second (Table 2). The SOM values determined in the muffle furnace, considered as standard method for Histosols (EMBRAPA, 2013), varied from 162.5 to $297.8 \mathrm{~g} \mathrm{~kg}^{-1}$ in the first year and from 153.7 to $310.3 \mathrm{~g} \mathrm{~kg}^{-1}$ in the second. The muffle values were generally greater than those calculated by the organic $\mathrm{C}$ method.

Table 2. Soil organic matter (SOM) values obtained by two methods, in the two years, for the treatments and depths

\begin{tabular}{|c|c|c|c|c|c|}
\hline \multirow{3}{*}{ Area } & \multirow{3}{*}{ Depth $(\mathrm{cm})$} & \multicolumn{4}{|c|}{$\mathrm{SOM}\left(\mathrm{g} \mathrm{kg}^{-1}\right)$} \\
\hline & & \multicolumn{2}{|c|}{ First Sampling 2009} & \multicolumn{2}{|c|}{ Second Sampling 2010} \\
\hline & & Calculated & Muffle & Calculated & Muffle \\
\hline Pasture & & 275.2Aa(a) & 282.7Aa(a) & $303.2 \mathrm{Aa}(\mathrm{a})$ & $310.3 \mathrm{Aa}(\mathrm{a})$ \\
\hline Bean & $0-10$ & 228.1ABa(a) & 277.2ABa(a) & 212.4ABa(a) & $220.3 \mathrm{ABa}(\mathrm{a})$ \\
\hline Cassava & & 142.9Ba(a) & $162.5 \mathrm{Ba}(\mathrm{a})$ & 145.4Ba(a) & $153.7 \mathrm{Ba}(\mathrm{a})$ \\
\hline Pasture & & 292.3Aa(a) & 297.8Aa(a) & 299.6Aa(a) & 322.9Aa(a) \\
\hline Bean & $10-20$ & 214.5ABa(a) & 229.2ABa(a) & 203.9ABa(a) & 222.4ABa(a) \\
\hline Cassava & & $152.2 \mathrm{Ba}(\mathrm{a})$ & $163.5 \mathrm{Ba}(\mathrm{a})$ & $142.1 \mathrm{Ba}(\mathrm{a})$ & $155.0 \mathrm{Ba}(\mathrm{a})$ \\
\hline $\mathrm{CV} \%$ & & 39.81 & 28.82 & 34.27 & 26.28 \\
\hline
\end{tabular}

\# The capital letters represents the treatments at the same depth; the small letters represent the depths within the same treatment; the letters in parentheses represent the samplings years. Calculated - SOM calculated from organic C values obtained from Embrapa (1997) and using a multiplication factor; Muffle - values obtained by the muffle furnace method of determining organic matter.

The distribution of SOM values in the surface reflected the soil management. The cassava presented the lowest SOM values in both methods and depths. In Histosols, Cipriano-Silva et al. (2014) found values between 175 and $181 \mathrm{~g} \mathrm{~kg}^{-1}$ when cultivated with sugarcane and cassava; and Moura et al. (2013) found values of 122 and $126 \mathrm{~g} \mathrm{~kg}^{-1}$ with cassava. These results indicate the effect of long period of cultivation and crop management, leading to intense SOM mineralization. According Moura et al. (2013), the decrease in SOM values were affected by drainage and soil tillage, influencing the temperature, humidity, soil aeration and supply of crop residues.

\section{Physical Properties of Histosols}

The particle density (Dp) values (Table 3 ) ranged from 1.31 to $1.91 \mathrm{Mg} \mathrm{m}^{-3}$; the total pore volume (TPV) varied between 50 and $69 \%$ and the high TPV values are common in Histosols. The bulk density values ranged from 0.53 to $0.77 \mathrm{Mg} \mathrm{m}^{-3}$ at the two depths, and there was a difference between the areas in the second year. The properties bulk density (BD), minimum residue (MR) and mineral material (MM) are related to SOM content and degree of decomposition (CONCEIÇÃO et al., 1999). The physical properties of Histosols are strongly influenced by the organic matter content that is used as an indicator of soil degradation.

The cassava site showed the greatest values of BD, MR and MM (Table 3) and the lowest of SOM (Table 2). These results indicate that agricultural practices in the cassava site had greatest soil impact in the SOM transformation and soil subsidence. Similar result was observed by Cipriano-Silva et al. (2014) in an area cultivated with sugarcane and cassava. The organic matter density (OMD) also is related to soil usage (Table 3). According to Kämpf \& Schneider (1989), values higher than $0.15 \mathrm{Mg} \mathrm{m}^{-3}$ are associated with intensively cultivated areas. The OMD values were greater than or equal to this value in all sites, with a variation between 0.15 and $0.27 \mathrm{Mg} \mathrm{m}^{-3}$. However, no significant differences were observed among sites or depths.

For the soil aggregation, in the first year, the MWD showed a difference among the sites at 0-10 $\mathrm{cm}$, with highest values in the cassava. The pasture showed variation in values of MWD, increasing with depth, and there were no differences in the other areas. The MWD ranged from 3.78 to 4.90 $\mathrm{mm}$. These values were higher than the data found by Moura et al. (2013) in Histossols in Brasilia, DF ( 2.4 to $2.84 \mathrm{~mm}$ ), and they are in accordance with Cardozo et al. (2008), studying Histosols in Nova Friburgo, RJ, under oleraceous crops $(4.10 \mathrm{~mm})$ and an area left fallow for 20 years $(3.42 \mathrm{~mm})$. The MWD values in all three studies are considered high when compared to other soils classes than Histosols, and this is attributed to the SOM, which is considered by many researchers as the primary agent stabilizing the aggregates (GANG et al., 1998). 
Table 3. Values of $\mathrm{Dp}$ and BD, total pores volume, organic matter density, minimum residue, mineral matter, and aggregate indexes of three Histosol areas with different usages, first and second samplings, at depths of $0-10$ and $10-20 \mathrm{~cm}$

\begin{tabular}{|c|c|c|c|c|c|c|c|c|c|}
\hline \multirow{2}{*}{ Area } & \multirow{2}{*}{$\begin{array}{l}\text { Depth } \\
(\mathrm{cm})\end{array}$} & \multirow{2}{*}{$\begin{array}{c}\mathrm{Dp} \\
\left(\mathrm{Mg} \mathrm{m}^{-3}\right)\end{array}$} & \multirow{2}{*}{$\begin{array}{c}\mathrm{BD} \\
\left(\mathrm{Mg} \mathrm{m}^{-3}\right)\end{array}$} & \multirow{2}{*}{$\begin{array}{l}\mathrm{TPV} \\
(\%)\end{array}$} & \multirow{2}{*}{$\begin{array}{c}\text { OMD } \\
\left(\mathrm{Mg} \mathrm{m}^{-3}\right)\end{array}$} & \multirow{2}{*}{$\begin{array}{c}\mathrm{MR} \\
\left(\mathrm{cm} \mathrm{cm}^{-1}\right)\end{array}$} & \multirow{2}{*}{$\begin{array}{l}\mathrm{MM} \\
(\%)\end{array}$} & \multicolumn{2}{|c|}{ Aggregate indexes } \\
\hline & & & & & & & & $\operatorname{MWD}(\mathrm{mm})^{*}$ & $\operatorname{GMD}(\mathrm{mm})^{*}$ \\
\hline & \multicolumn{9}{|c|}{ First Sampling - 2009} \\
\hline Pasture & & $1.50 \mathrm{Aa}(\mathrm{a})$ & $0.68 \mathrm{Aa}(\mathrm{a})$ & $55 \mathrm{Aa}(\mathrm{a})$ & $0.26 \mathrm{Aa}(\mathrm{a})$ & $0.28 \mathrm{Aa}(\mathrm{a})$ & $61.0 \mathrm{Aa}(\mathrm{a})$ & $3.78 \mathrm{Bab}(\mathrm{b})$ & $0.10 \mathrm{Ba}(\mathrm{b})$ \\
\hline Bean & $0-10$ & $1.55 \mathrm{Aa}(\mathrm{a})$ & $0.57 \mathrm{Aa}(\mathrm{a})$ & $64 \mathrm{Aa}(\mathrm{a})$ & $0.20 \mathrm{Aa}(\mathrm{a})$ & $0.24 \mathrm{Aa}(\mathrm{a})$ & $63.9 \mathrm{Aa}(\mathrm{a})$ & $4.18 \mathrm{ABa}(\mathrm{a})$ & $0.26 \mathrm{ABa}(\mathrm{a})$ \\
\hline Cassava & & $1.67 \mathrm{Aa}(\mathrm{a})$ & $0.72 \mathrm{Aa}(\mathrm{a})$ & $57 \mathrm{Aa}(\mathrm{a})$ & $0.24 \mathrm{Aa}(\mathrm{a})$ & $0.32 \mathrm{Aa}(\mathrm{a})$ & $66.6 \mathrm{Aa}(\mathrm{a})$ & $4.90 \mathrm{Aa}(\mathrm{a})$ & $0.46 \mathrm{Aa}(\mathrm{a}$ \\
\hline Pasture & & $1.50 \mathrm{Aa}(\mathrm{a})$ & $0.67 \mathrm{Aa}(\mathrm{a})$ & $55 \mathrm{Aa}(\mathrm{a})$ & $0.27 \mathrm{Aa}(\mathrm{a})$ & $0.27 \mathrm{Aa}(\mathrm{a})$ & $59.9 \mathrm{Aa}(\mathrm{a})$ & $4.31 \mathrm{Aa}(\mathrm{a})$ & $0.09 \mathrm{Aa}(\mathrm{b})$ \\
\hline Bean & $10-20$ & $1.31 \mathrm{Aa}(\mathrm{a})$ & $0.64 \mathrm{Aa}(\mathrm{a})$ & $50 \mathrm{Aa}(\mathrm{b})$ & $0.19 \mathrm{Aa}(\mathrm{a})$ & $0.30 \mathrm{Aa}(\mathrm{a})$ & $71.0 \mathrm{Aa}(\mathrm{a})$ & $4.49 \mathrm{Aa}(\mathrm{a})$ & $0.18 \mathrm{Aa}(\mathrm{a})$ \\
\hline \multirow[t]{2}{*}{ Cassava } & & $1.65 \mathrm{Aa}(\mathrm{a})$ & $0.69 \mathrm{Aa}(\mathrm{a})$ & $58 \mathrm{Aa}(\mathrm{a})$ & $0.22 \mathrm{Aa}(\mathrm{a})$ & $0.31 \mathrm{Aa}(\mathrm{a})$ & $67.4 \mathrm{Aa}(\mathrm{a})$ & $4.86 \mathrm{Aa}(\mathrm{a})$ & $0.26 \mathrm{Aa}(\mathrm{a})$ \\
\hline & \multicolumn{9}{|c|}{ Second Sampling - 2010} \\
\hline Pasture & & $1.51 \mathrm{Aa}(\mathrm{a})$ & $0.53 \mathrm{Ba}(\mathrm{a})$ & $65 \mathrm{Aa}(\mathrm{a})$ & $0.24 \mathrm{Aab}(\mathrm{a})$ & $0.21 \mathrm{Ba}(\mathrm{a})$ & 57.1 Bab(a) & $4.26 \mathrm{Aa}(\mathrm{a})$ & $0.26 \mathrm{Aa}(\mathrm{b})$ \\
\hline Bean & $0-10$ & $1.62 \mathrm{Aa}(\mathrm{a})$ & $0.50 \mathrm{Ba}(\mathrm{a})$ & $69 \mathrm{Aa}(\mathrm{a})$ & $0.16 \mathrm{Aa}(\mathrm{a})$ & $0.22 \mathrm{Ba}(\mathrm{a})$ & $67.9 \mathrm{ABa}(\mathrm{a})$ & $4.14 \mathrm{Aa}(\mathrm{a})$ & $0.33 \mathrm{Aa}(\mathrm{a})$ \\
\hline Cassava & & $1.91 \mathrm{Aa}(\mathrm{a})$ & $0.76 \mathrm{Aa}(\mathrm{a})$ & $60 \mathrm{Aa}(\mathrm{a})$ & $0.15 \mathrm{Aa}(\mathrm{a})$ & $0.46 \mathrm{Aa}(\mathrm{a})$ & $81.6 \mathrm{Aa}(\mathrm{a})$ & $4.22 \mathrm{Aa}(\mathrm{a})$ & $0.13 \mathrm{Aa}(\mathrm{b})$ \\
\hline Pasture & & $1.51 \mathrm{Aa}(\mathrm{a})$ & $0.54 \mathrm{Ba}(\mathrm{a})$ & $64 \mathrm{Aa}(\mathrm{a})$ & $0.24 \mathrm{Aab}(\mathrm{a})$ & $0.18 \mathrm{Ba}(\mathrm{a})$ & $53.3 \mathrm{Bb}(\mathrm{a})$ & $4.37 \mathrm{Aa}(\mathrm{a})$ & $0.37 \mathrm{Aa}(\mathrm{a})$ \\
\hline Bean & $10-20$ & $1.61 \mathrm{Aa}(\mathrm{a})$ & $0.54 \mathrm{Ba}(\mathrm{a})$ & $66 \mathrm{Aa}(\mathrm{a})$ & $0.17 \mathrm{Aa}(\mathrm{a})$ & $0.22 \mathrm{Ba}(\mathrm{a})$ & $66.2 \mathrm{ABa}(\mathrm{a})$ & $4.45 \mathrm{Aa}(\mathrm{a})$ & $0.28 \mathrm{Aa}(\mathrm{a})$ \\
\hline Cassava & & $1.88 \mathrm{Aa}(\mathrm{a})$ & $0.77 \mathrm{Aa}(\mathrm{a})$ & $56 \mathrm{Aa}(\mathrm{a})$ & $0.16 \mathrm{Aa}(\mathrm{a})$ & $0.44 \mathrm{Aa}(\mathrm{a})$ & $80.7 \mathrm{Aa}(\mathrm{a})$ & $4.51 \mathrm{Aa}(\mathrm{a})$ & $0.16 \mathrm{Aa}(\mathrm{a})$ \\
\hline
\end{tabular}

Dp - particle density; Ds - bulk soil density; TPV - total pore volume, OMD - organic matter density; MR - minimum residue, MM - mineral matter; MWD - mean weight diameter; GMD geometric mean diameter. \# The capital letters represents the treatments at the same depth; the small letters represent the depths within the same treatment; the letters in parentheses represent the samplings. ${ }^{*}$ CV (\%) First Sampling: MWD - 13.47; GMD - 57.81 ; Second Sampling: MWD - 11.10; GWD - 51.32 
The geometric mean diameter (GMD) varied from 0.09 to $0.46 \mathrm{~mm}$. In the first year, the GMD showed a significant difference, with the largest diameter in cassava site at $0-10 \mathrm{~cm}$. The low MWD and GMD values at $0-10 \mathrm{~cm}$ in the pasture may be related to cattle trampling. The highest values were observed in cassava site, where repetition of wet/dry cycles promoted by ridge planting and furrow irrigation leads to the formation of larger aggregates.

\section{Fractionation of Humic Substances and Stocks of Carbon and Nitrogen in the Soil}

The distribution of humic fractios of SOM at the sites indicate predominance of humin fraction
(HUM-C), followed by humic acid (HAF-C) and fulvic acid (FAF-C) (Table 4). The predominance of humin was also reported by others authors in Histosols and soils with high organic-matter content from different regions of Brazil (VALLADARES et al. 2007; FONTANA et al. 2008; CIPRIANO-SILVA et al, 2014). Two factors may explain the $\mathrm{C}$ dominance in the humin fraction in hydromorphic environments; the first is related to direct humidification of lignified tissues modified by demethylation processes, which is favored by reduction of insolubilization and mechanisms of microbial neossintese; and the second is related to presence of hereditary humin (ORLOV, 1985; TAN 2003).

Table 4. Carbon content in the humic substances fractions: humin (HUM-C), humic acid (HAF-C) and fulvic acid (FAF-C), and HAF-C/FAF-C ratio; and carbon and nitrogen stocks at $0-10$ and $10-20 \mathrm{~cm}$ depth.

\begin{tabular}{|c|c|c|c|c|c|c|c|}
\hline \multirow[b]{2}{*}{ Area } & \multirow{2}{*}{$\begin{array}{l}\text { Depth } \\
(\mathrm{cm})\end{array}$} & \multirow{2}{*}{$\begin{array}{l}\text { HUM-C } \\
\left(\mathrm{g} \mathrm{kg}^{-1}\right)\end{array}$} & \multirow{2}{*}{$\begin{array}{l}\text { HAF-C } \\
\left(\mathrm{g} \mathrm{kg}^{-1}\right)\end{array}$} & \multirow{2}{*}{$\begin{array}{l}\text { FAF-C } \\
\left(\mathrm{g} \mathrm{kg}^{-1}\right)\end{array}$} & \multirow{2}{*}{$\begin{array}{c}\text { HAF-C/FAF-C } \\
\left(\mathrm{g} \mathrm{kg}^{-1}\right)\end{array}$} & \multicolumn{2}{|c|}{$\operatorname{Stock}^{1}\left(\mathrm{Mg} \mathrm{ha}^{-1}\right)$} \\
\hline & & & & & & Carbon* & Nitrogen ${ }^{*}$ \\
\hline & \multicolumn{7}{|c|}{ First Sampling - 2009} \\
\hline Pasture & \multirow{3}{*}{$0-10$} & $115.58 \mathrm{Aa}(\mathrm{a})$ & $29.80 \mathrm{Aa}(\mathrm{b})$ & $13.78 \mathrm{Bb}(\mathrm{b})$ & $2.18 \mathrm{Aa}(\mathrm{a})$ & 115.92Aa(a) & 8.35Aa(a) \\
\hline Bean & & $90.64 \mathrm{Aa}(\mathrm{a})$ & $28.32 \mathrm{Aa}(\mathrm{a})$ & $13.34 \mathrm{Bb}(\mathrm{a})$ & $2.19 \mathrm{Aa}(\mathrm{a})$ & 81.69Ba(a) & $5.41 \mathrm{ABa}(\mathrm{a})$ \\
\hline Cassava & & $77.26 \mathrm{Aa}(\mathrm{a})$ & $35.38 \mathrm{Aa}(\mathrm{a})$ & $22.67 \mathrm{Aa}(\mathrm{a})$ & $1.57 \mathrm{Aa}(\mathrm{a})$ & $104.98 \mathrm{ABa}(\mathrm{a})$ & $1.86 \mathrm{Ba}(\mathrm{a})$ \\
\hline Pasture & \multirow{3}{*}{$10-20$} & 118.47 Aa(a) & $26.52 \mathrm{Aa}(\mathrm{a})$ & $24.10 \mathrm{Aa}(\mathrm{a})$ & $1.22 \mathrm{Aa}(\mathrm{a})$ & $115.34 \mathrm{Aa}(\mathrm{a})$ & 7.76Aa(a) \\
\hline Bean & & $69.64 \mathrm{Aa}(\mathrm{b})$ & $29.03 \mathrm{Aa}(\mathrm{a})$ & $25.24 \mathrm{Aa}(\mathrm{a})$ & $1.24 \mathrm{Aa}(\mathrm{a})$ & $78.72 \mathrm{Ba}(\mathrm{a})$ & 3.01 ABab(a) \\
\hline \multirow[t]{2}{*}{ Cassava } & & $75.68 \mathrm{Aa}(\mathrm{a})$ & $32.34 \mathrm{Aa}(\mathrm{a})$ & $29.28 \mathrm{Aa}(\mathrm{a})$ & $1.14 \mathrm{Aa}(\mathrm{a})$ & $97.27 \mathrm{ABa}(\mathrm{a})$ & $2.34 \mathrm{Ba}(\mathrm{a})$ \\
\hline & & \multicolumn{6}{|c|}{ Second Sampling - 2010} \\
\hline Pasture & & 186.36 Aa(a) & $82.50 \mathrm{Aa}(\mathrm{a})$ & $54.37 \mathrm{Aa}(\mathrm{a})$ & $1.54 \mathrm{Aa}(\mathrm{a})$ & $99.35 \mathrm{Aa}(\mathrm{a})$ & $4.45 \mathrm{Aa}(\mathrm{b})$ \\
\hline Bean & $0-10$ & $100.62 \mathrm{ABa}(\mathrm{a})$ & $49.34 \mathrm{Ba}(\mathrm{a})$ & $17.62 \mathrm{Ba}(\mathrm{a})$ & $2.21 \mathrm{Aa}(\mathrm{a})$ & 74.67Aa(a) & $2.56 \mathrm{Ba}(\mathrm{b})$ \\
\hline Cassava & & $79.05 \mathrm{Ba}(\mathrm{a})$ & $44.56 \mathrm{Ba}(\mathrm{a})$ & $15.90 \mathrm{Ba}(\mathrm{a})$ & $2.80 \mathrm{Aa}(\mathrm{a})$ & 83.16Aa(a) & $1.23 \mathrm{Ba}(\mathrm{a})$ \\
\hline Pasture & & 135.36 Aa(a) & $58.20 \mathrm{Aa}(\mathrm{a})$ & $35.87 \mathrm{Aa}(\mathrm{a})$ & $1.66 \mathrm{Aa}(\mathrm{a})$ & $113.65 \mathrm{Aa}(\mathrm{a})$ & $5.32 \mathrm{Aa}(\mathrm{b})$ \\
\hline Bean & $10-20$ & $125.79 \mathrm{Aa}(\mathrm{a})$ & $67.50 \mathrm{Aa}(\mathrm{a})$ & $42.86 \mathrm{Aa}(\mathrm{a})$ & $2.05 \mathrm{Aa}(\mathrm{a})$ & $70.62 \mathrm{Ba}(\mathrm{a})$ & $1.97 \mathrm{Ba}(\mathrm{b})$ \\
\hline Cassava & & $77.19 \mathrm{Ba}(\mathrm{a})$ & $42.76 \mathrm{Aa}(\mathrm{a})$ & $17.00 \mathrm{Ba}(\mathrm{b})$ & $2.54 \mathrm{Aa}(\mathrm{a})$ & $88.65 \mathrm{Ba}(\mathrm{a})$ & $1.69 \mathrm{Ba}(\mathrm{a})$ \\
\hline
\end{tabular}

${ }^{1}$ Carbon and nitrogen determined by the dry combustion method in a CHN analyzer (LECO); \# The capital letters represent the treatments at the same depth; the small letters represent the depths within the same treatment; the letters in parentheses represent the samplings. ${ }^{*} \mathrm{CV}(\%)$ First Sampling: C - 33.20; N - 36.48; Second Sampling: C - 19.03; N - 22.85

There was a large variation in the HUM-C values for both depths; however, there was no difference among the sites in the first year. The HAF-C values did not differ, and FAF-C values only did so in the top layer $(0-10 \mathrm{~cm})$, with the highest value in the cassava site. There was no variation with depth for the $\mathrm{C}$ in SOM fractions (except for FAF-C in the first year), suggesting a similar SOM transformation processes of these Histosols.

In the second year (Table 4), the HUM-C fraction presented a significant difference in both depths, in general with the same distribution and ranging from 77.19 to $186.36 \mathrm{~g} \mathrm{~kg}^{-1}$. Pasture having the highest values, followed by bean and then cassava, a pattern that agrees with variation in SOM values. For HAF-C values, there was significative variation among sites only at $0-10 \mathrm{~cm}$, and for FAF$\mathrm{C}$ values in both depths, with the highest values in pasture site. The lowest values were in the cassava, and there was no variation with depth. The HAF$\mathrm{C} / \mathrm{FAF}-\mathrm{C}$ ratio ranged from 1.14 to 2.19 , similar to results found by Fontana (2008), and the values 
higher than 2.0 indicate dominance of $\mathrm{HAF}-\mathrm{C}$ in the Histosols.

There were differences in the carbon stocks (Table 4) for the first year, where the highest values were in pasture (115.92 and $115.34 \mathrm{Mg} \mathrm{ha}^{-1}$, for 0 10 and 10-20 cm respectively), followed by cassava and then bean. The same sequence was observed in the second year, the pasture having the highest stocks at $10-20 \mathrm{~cm}\left(113.65 \mathrm{Mg} \mathrm{ha}^{-1}\right)$. The higher $\mathrm{C}$ stocks in pasture at the surface are related to the capacity of this system to add organic $\mathrm{C}$ to the soil by grass shoots and roots, leading to $\mathrm{C}$ increases in relation to other soil uses (D'ANDRÉA et al., 2002).

There were variations in the nitrogen stocks in the first year among the sites (Table 4). The pasture had the highest values, at depths of 0-10, 10$20 \mathrm{~cm}$, followed by bean, then cassava. The variation for pasture was the same in the second year. Between the years, the pasture presented the highest values in the first sampling at both depths. In beans, the highest $\mathrm{N}$ stock was in the first sampling, at depths of 0-10 and 10-20 cm.

Since $\mathrm{N}$ is found in Histosols mainly in organic form, changes in SOM levels are accompanied by similar alterations in $\mathrm{N}$ stock. These attributes can help the development of sustainable technologies as well as help in the assessment of the soil's role as a source or sink of C-CO $\mathrm{CO}_{2}$ and $\mathrm{N}-\mathrm{N}_{2} \mathrm{O}$ (CORAZZA et al., 1999).

\section{Integration of Results for the Attributes of Histosols}

To distinguish possible effects of soil management, a principal components analysis (PCA) was used to rank the attributes, which were summarized in a graph with perpendicular axes, representing multidimensional variation of a set of data as a function of soil usage. This analysis showed a strong effect of soil management by a clear separation of the three sites, shown by the position of the vectors in Figure 1a. In this respect, axis 1 was responsible for the separation of the bean site from the other two usages, with this site's data appearing above the horizontal line. The PCA presented good significance, with the sum of the eigenvalues reaching $74.1 \%$.

The data in Figure 1b show variable results within the usages, separating the cassava site, but not clearly distinguishing the pasture and the bean sites. This figure presents all the values and variables analyzed in the form of vectors, showing each variable's influence. Therefore, the nearest the attributes (variables) are, the more often they occur together. The pasture was associated with most of attributes related to $\mathrm{C}$ content as well as the state of organic matter transformation: C_CHN, H_CHN, N_CHN, soil SOM_muffle, N_distiller, OMD, $\mathrm{Al}^{3+}$, $\mathrm{H}^{+}$, HUM-C and FAF-C. These attributes are directly related to recent and steady influx of organic matter in the soil, added to those that indicate less intervention by soil preparation.

due to their fasciculate root system, with a high density of fine roots and constant root renewal. Thus, they are an important source of carbon for the soil. Addition of organic matter during decomposition process adds into the soil aminoacids, $\mathrm{CO}_{2}$ and carboxylic acids, the main factors responsible for the increase of $\mathrm{H}^{+}$ions in the soil solution. The bean field occupied an intermediate position with respect to the attributes and showed a direct relationship with $\mathrm{C}$. But it stood out for attributes such as $\mathrm{pH}_{-} \mathrm{KCl}, \mathrm{FAH} / \mathrm{FAF}$, HAF-C, SOM_WB, StC_WB, TPV, GMC, $\mathrm{Al}^{3+}$ and $\mathrm{H}^{+}$.

The levels of $\mathrm{Al}^{3+}$ and $\mathrm{H} \_\mathrm{CHN}$ were not specifically associated with any of the usages, but were instead found at the intersection between pasture and bean sites. Since these two were near each other, both in Macaé (RJ), these attributes may be related to characteristics inherited from the organic matter and mineral sediments that formed the Histosols. For the cassava site, there was a cluster of chemical attributes regarding soil fertility along with physical attributes indicative of the crop management. The attributes common to this usage were: $\mathrm{Ca}, \mathrm{Mg}, \mathrm{Na}, \mathrm{K}, \mathrm{P}, \mathrm{S}, \mathrm{T}, \mathrm{V}, \mathrm{pH}$ (water, $\mathrm{CaCl}_{2}$ ), BD, Dp, MWD, GMD, MR and MM. The values related to soil fertility are explained by the greater usage of agriculture practices for a longer period. In turn, the physical attributes indicate an advanced subsidence and/or soil degradation process.

\section{Grasses Promote Greater Addition of Carbon in Soil}

The multivariate analysis was important to distinguish the usages. The values found and discussed separately above show that the soil management in the pasture site to a certain extent promotes conservation of organic carbon, while the management of the cassava is more aggressive, causing greater degradation and reducing the carbon stock. 

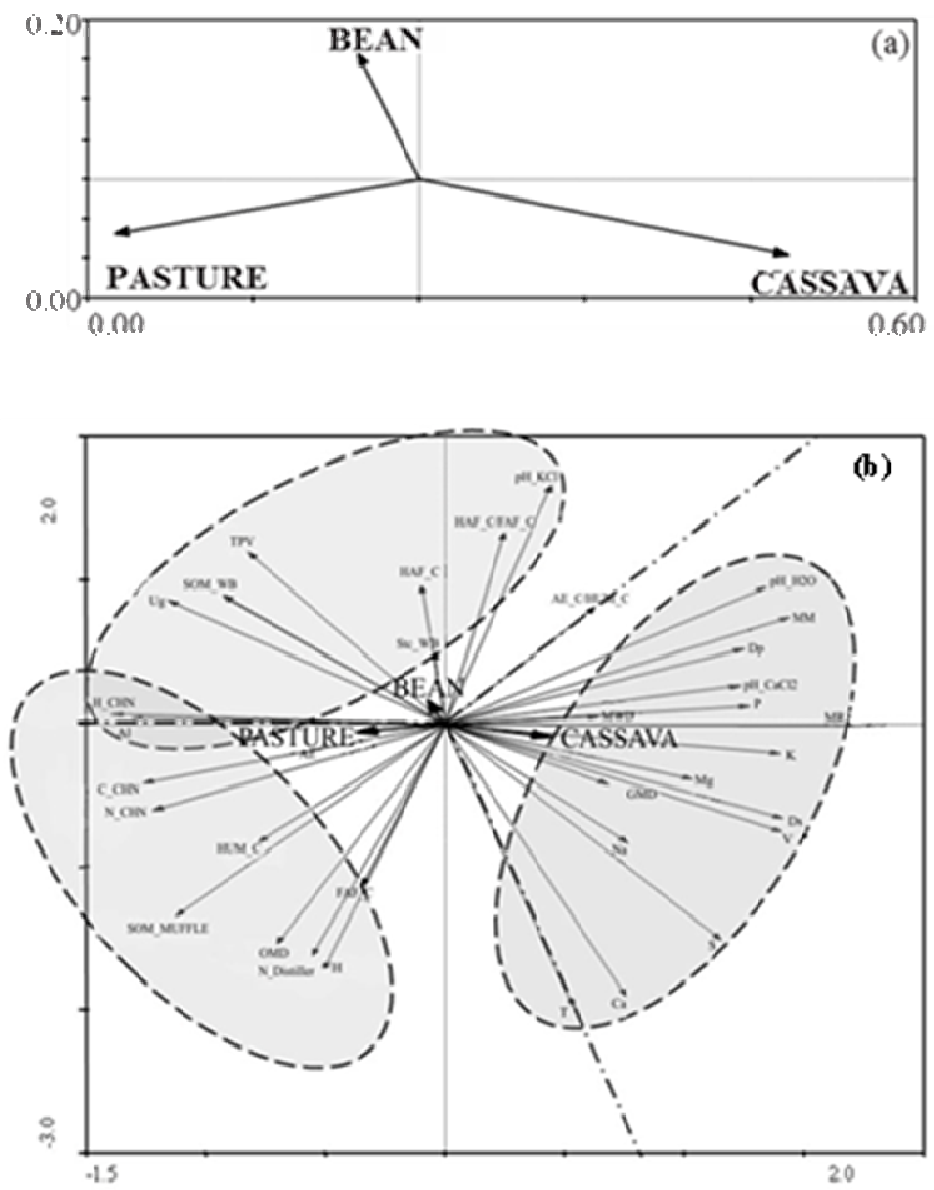

Figure 1. Principal components analysis of the soil attributes with emphasis on discrimination of the usages (a); and general analysis of influence of the soil attributes with emphasis on clustering as a function of usages (b) (Axis 1- 61.8\% and Axis $2-12.3 \%$ ).

\section{Emission of $\mathrm{CO}_{2}$ and $\mathrm{N}_{2} \mathrm{O}$ from the Histosols}

The emissions of $\mathrm{CO}_{2}$ and $\mathrm{N}_{2} \mathrm{O}$ were calculated from the data obtained in the field and analyzed by comparing against the greenhouse gas emission database of the IPCC (1997). Although the number of measurements was too small to be certain of the real emission pattern during the growing cycle, the data are still original and important because of the scarcity of studies in the literature on Histosols. The $\mathrm{CO}_{2}$ flux (Figure 2-ab) was greatest in the first year in the bean site $\left(0.09 \mathrm{Mg} \mathrm{CO}_{2} \mathrm{ha}^{-1}\right.$ day $^{-1}$ ) among all measurements during the four sampling days. This high $\mathrm{CO}_{2}$ flux was possible due to addition of crop residue (leguminous $\mathrm{N}_{2}$ fixer), causing a lower $\mathrm{C} / \mathrm{N}$ ratio, which favored the $\mathrm{OM}$ decomposition by aerobic microorganisms, increasing the flux of $\mathrm{CO}_{2}$. At the first sampling, the crop was in maturation stage, with a large proportion of leaves in senescence, increasing input of $\mathrm{N}$ in the soil. Giacomine et al. (2008) also observed a tendency for greater emissions after the addition of plant material. The authors theorized that organic compounds, which decompose easily, are mineralized after microbial population adapts to the substrate, and in the process $\mathrm{CO}_{2}$ is also emitted by root respiration.

For the second year, the highest $\mathrm{CO}_{2}$ emissions were observed in the pasture, with high flux on all four measurement days and the highest value on the third day $\left(0.10 \mathrm{Mg} \mathrm{CO}_{2} \mathrm{ha}^{-1}\right.$ day $\left.^{-1}\right)$. At that period, the bean and cassava fields had already been harvested and there were no plant residues, unlike the pasture, where the grass was about $80 \mathrm{~cm}$ tall and there was a layer of plant residues about 5 $\mathrm{cm}$ thick, thus a large proportion of biomass was steadily introduced in the soil to continue the process of transforming the SOM. Besides this, the dense grass root system intensified the emission of $\mathrm{CO}_{2}$ by the respiration process. The $\mathrm{CO}_{2}$ fluxes oscillated during the samplings, although with a tendency for higher values in the second year. 

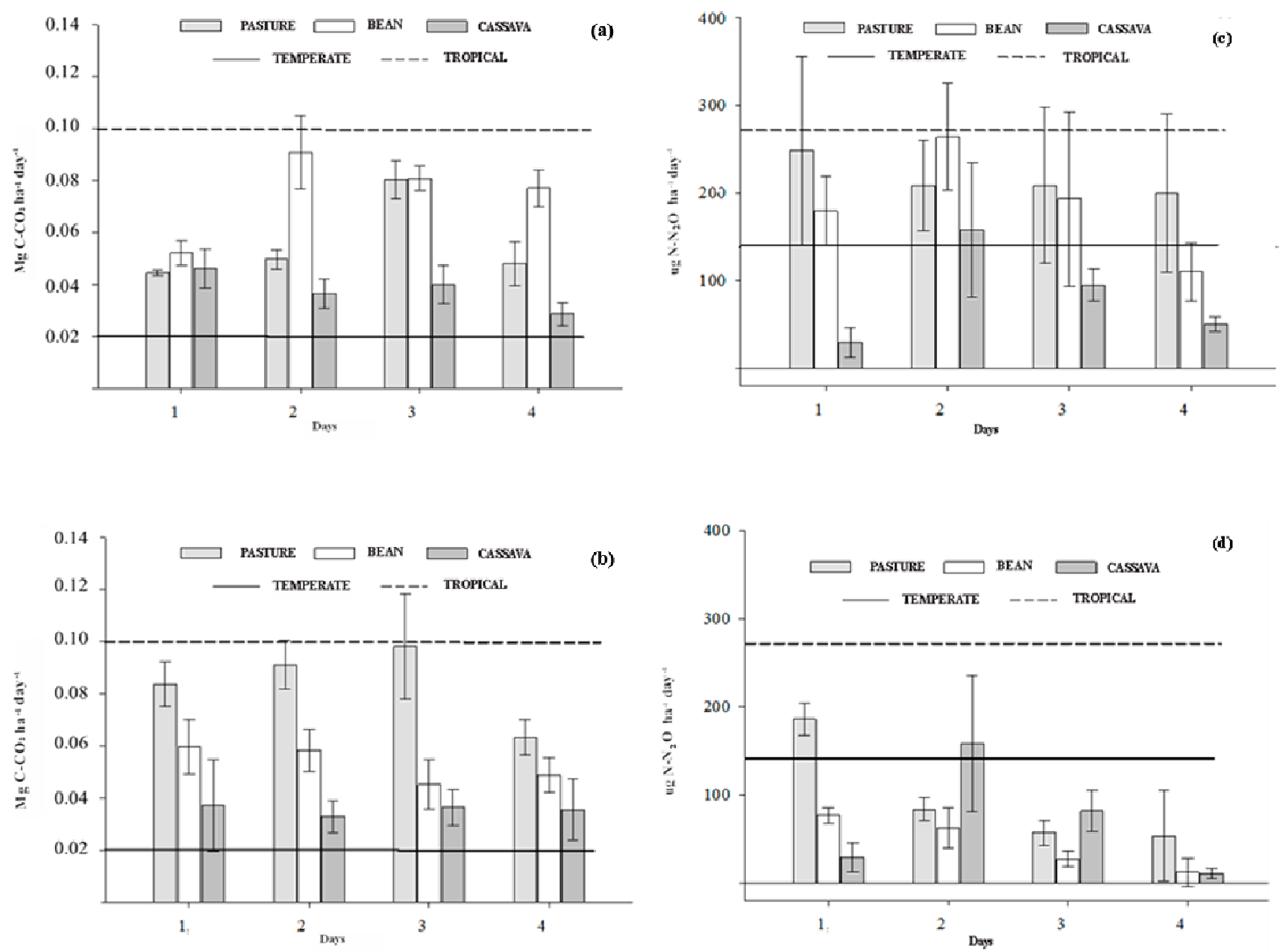

Figure 2. $\mathrm{C} \_\mathrm{CO}_{2}$ emissions on different sampling days (x-axis) in function of soil usage, first sampling (a) and second sampling (b). $\mathrm{N}_{-} \mathrm{N}_{2} \mathrm{O}$ emissions on different sampling days (x-axis) in function of soil usage, first sampling (c) and second sampling (d). The values were submitted to the Tukey test $(0.05>\mathrm{p})$. The dotted line indicates the typical emission in a tropical climate and the solid line in a temperate climate.

Organic matter decomposes in tropical climates twice as fast as in temperate climates (IPCC, 1997). As a consequence, the $\mathrm{CO}_{2}$ flux from Histosols is also greater in tropical regions, varying from $0.02 \mathrm{Mg}$ C_CO $\mathrm{CO}_{2} \mathrm{ha}^{-1}$ day $^{-1}$ in temperate climates to $0.10 \mathrm{Mg} \mathrm{C} \_\mathrm{CO}_{2} \mathrm{ha}^{-1}$ day $^{-1}$ in tropical ones. The $\mathrm{CO}_{2}$ flux values in this study are in accordance with IPCC data for Histosols in tropical regions.

Regarding $\mathrm{N}_{2} \mathrm{O}$ (Figure 2-cd), for the first year the highest flux occurred in the bean site on the second day, at about $270 \mu \mathrm{g} \mathrm{N}-\mathrm{N}_{2} \mathrm{O} \mathrm{m}{ }^{-2}$ day $^{-1}$. On the other days, the highest emissions came from the pasture. The $\mathrm{N}_{2} \mathrm{O}$ fluxes in these two usages did not differ, while the lowest values occurred in the cassava site. The high values in the pasture are possibly related to the continuous addition of $\mathrm{N}$ (JANTALIA et al., 2006), and in the bean site due to releasing of $\mathrm{N}$ to the soil from decomposition of fallen leaves. For the second year the highest $\mathrm{N}_{2} \mathrm{O}$ flux occurred in the pasture on the first day, with values of $180 \mu \mathrm{g} \mathrm{N}-\mathrm{N}_{2} \mathrm{O} \mathrm{m}{ }^{-2}$ day $^{-1}$. On the other days no variation or pattern was observed in the $\mathrm{N}_{2} \mathrm{O}$ flux.

There are few published studies of gas emissions from Histosols in tropical regions, making comparison and validation of the data hard. However, the $\mathrm{C}-\mathrm{CO}_{2}$ flux values are within the emission range proposed by the IPCC, while the N$\mathrm{N}_{2} \mathrm{O}$ values are lower. Based on this study, although preliminary, nitrous oxide emission rates proposed for cultivated Histosols in tropical regions are overestimated.

\section{CONCLUSIONS}

The cassava site had the highest levels of sorption complex elements, as a direct influence of fertilization and soil management. 
The physical properties: soil bulk density, particle density, mineral matter, mineral residue and organic matter density indicated highest alterations of Histosols properties with agricultural usage.

The cassava showed most transformation of soil organic matter.

In all sites, the carbon levels in the organic fractions indicated predominance of HUM-C. The SOM and the stocks of $\mathrm{C}$ and $\mathrm{N}$ were highest in the pasture, which was considered the best usage in terms of conserving SOM.

The clusters obtained through multivariate analysis allowed to stratify the three usages. The pasture stood out as showing the least alteration of soil properties.
Although C- $\mathrm{CO}_{2}$ and $\mathrm{N}-\mathrm{N}_{2} \mathrm{O}$ flux data were obtained from a small number of samples, preliminary values of $\mathrm{C}-\mathrm{CO}_{2}$ emission were within the range proposed by the IPCC, while the $\mathrm{N}-\mathrm{N}_{2} \mathrm{O}$ values were lower.

\section{ACKNOWLEDGEMENTS}

The authors acknowledge the Pesagro-Rio for experimental areas, and technicians of UFRRJ for analyses assistance. Thanks are extended to the Brazilian Federal Agency CAPES for financial support through the Graduate Course in Agronomy - Soil Science (CPGA-CS / UFRRJ), as well as the $\mathrm{CNPq}$ and the FAPERJ for scholarships issued to the authors and for financing the project.

RESUMO: Os Organossolos são reservatório natural de C no solo e sua drenagem seguida por práticas agrícolas leva a subsidência e transformações na matéria orgânica do solo. O objetivo do estudo é avaliar a influencia do uso e manejo de Organossolos, através da: caracterização de propriedades químicas e físicas, conteudo de matéria orgânica do solo e frações húmicas; e quantificação de estoques de $\mathrm{C}$ e N. Ainda, obter dados preliminares sobre emissão de gases de efeito estufa $\left(\mathrm{CO}_{2}, \mathrm{~N}_{2} \mathrm{O}\right)$ em áreas de Organossolos com diferentes usos agrícolas. Foram selecionadas três áreas com solos e ambientes semelhantes, duas no município de Macaé, sob pastagem e feijão com rotação de lavouras, e a terceira em Santa Cruz na cidade do Rio de Janeiro, com mandioca (Manihot esculenta). Os atributos avaliados foram: físicos densidade do solo (Ds), densidade de partículas (Dp), densidade de matéria orgânica (DMO), material mineral (MM), resíduo mineral $(\mathrm{RM})$, estabilidade de agregados; químicos - $\mathrm{pH}$, cátions trocáveis, matéria orgânica do solo (MOS), carbono nas frações humina (HUM-C), ácido húmico (FAH-C) e ácido fúlvico (FAF-C); estoques de C e N; e fluxo de $\mathrm{CO}_{2}$ e $\mathrm{N}_{2} \mathrm{O}$. A área de mandioca apresentou maiores valores de cátions trocáveis como resultado das práticas de adubação e manejo do solo. A área de mandioca apresentou Ds e Dp, volume total de poros, e valores de MM e RM e DMO mais elevados, e maior grau de transformação da matéria orgânica, indicando maior alteração das propriedades do Organossolo com esse uso. Em todas as áreas, os teores de $\mathrm{C}$ indicaram predomínio da humina. Os valores de MOS e estoques de $\mathrm{C}$ e $\mathrm{N}$ foram maiores na pastagem, indicando melhor preservação da matéria orgânica, com valores variando de $115,92-99,35 \mathrm{Mg}$ $\mathrm{ha}^{-1}$ de C e 8,35-4,45 $\mathrm{Mg} \mathrm{ha}^{-1}$ para $\mathrm{N}$. Os valores de fluxo de $\mathrm{CO}_{2}$ estão de acordo com o IPCC, sendo o mais elevado de $0,09 \mathrm{mg}$ de $\mathrm{CO}_{2} \mathrm{ha}^{-1} \mathrm{dia}^{-1}$ na pastagem. Para $\mathrm{N}_{2} \mathrm{O}$ os fluxos foram menores que o proposto pelo IPCC, com o maior valor de $270 \mathrm{~g} \mathrm{~N}_{2} \mathrm{O}-\mathrm{N} \mathrm{m}^{-2}$ dia $^{-1}$ na área com feijão. Em geral, a análise multivariada discriminou as áreas e a pastagem foi o uso que menos afetou as propriedades dos Organossolos.

PALAVRAS-CHAVE: Substâncias Húmicas. Estoques de C e N, Emissões de $\mathrm{N}_{2} \mathrm{O}$ e de $\mathrm{CO}_{2}$.

\section{REFERENCES}

ALVES, B. J. R; SMITHB, K. A; FLORES, R. A.; CARDOSO, A. S; OLIVEIRA, W. R. D.; JANTALIA, C. P.; URQUIAGA, S.; BODDEY, R. M. Selection of the most suitable sampling time for static chambers for the estimation of daily mean N2O flux from soils. Soil Biology and Biochemistry, Elmsford, v. 46, n. 1, p. 129135, 2012. http://dx.doi.org/10.1016/j.soilbio.2011.11.022

BATJES, N. H. Total carbon and nitrogen in the soils of the world. European Journal of Soil Science, Amsterdam, v. 47, n. 2, p. 151-163,1996. http://dx.doi.org/10.1111/j.1365-2389.1996.tb01386.x

BENITES, V. M., MADARI, B., MACHADO, P. L. O. A. Extração e fracionamento quantitativo de substâncias húmicas do solo: um procedimento simplificado de baixo custo. Rio de Janeiro: Embrapa Solos, 2003. p. 7. 
CARDOZO, S. V.; PEREIRA, M. G.; LOSS, A.; RAVELLI, A. Caracterização de propriedades edáficas em áreas sob manejo orgânico e natural na região serrana do Estado do Rio de Janeiro. Semina. Ciências Agrárias, Londrina, v. 29, n. 3, p. 517-530, 2008

CERRI, C. E. P., SPAROVEK, G., BERNOUX, M., EASTERLING, W. E., MELILLO, J. M., CERRI, C. C. Tropical agriculture and global warming: impacts and mitigation options. Scientia Agricola, Piracicaba, v. 64, n. 1, p. 83-99, 2007. http://dx.doi.org/10.1590/S0103-90162007000100013

CIPRIANO-SILVA, R., VALLADARES, G. S., PEREIRA, M. G., ANJOS, L. H. C. Caracterização de Organossolos em ambientes de várzea do nordeste do Brasil. Revista Brasileira de Ciência do Solo, Viçosa, v. 38, n. 1, p. 26-38, 2014.

CONCEIÇÃO, M., MANZATTO, C. V., ARAÚJO W. S., MARTIN NETO, L., SAAB, S. C., CUNHA, T. J. F., FREIXO, A. A. Caracterização de solos Orgânicos do Estado do Rio de Janeiro, propriedades físicas e morfológicas como subsídios à classificação. Rio de Janeiro: Embrapa Solos, v. 4, 1999. 6 p.

CORAZZA, E. J., SILVA, J. E., RESCK, D. V. S., GOMES, A. C. Comportamento de diferentes sistemas de manejo como fonte ou depósito de carbono em relação à vegetação de Cerrado. Revista Brasileira de Ciência do Solo, Viçosa, v. 23, n. 2, p. 425-432, 1999.

D’ANDRÉA, A. F., SILVA, M. L. N., CURI, N., SIQUEIRA, J. O., CARNEIRO, M. A. C. Atributos biológicos indicadores da qualidade do solo em sistemas de manejo na região do Cerrado no sul do Estado de Goiás. Revista Brasileira de Ciência do Solo, Viçosa, v. 26, n. 4, p. 913- 923, 2002.

EBELING, A. G., ANJOS, L. H. C., PEREZ, D. V., PEREIRA, M. G., VALLADARES, G. S. Relação entre acidez e outros atributos químicos em solos com teores elevados de matéria orgânica. Bragantia, Campinas, v. 67, n. 2, p. 261-266, 2008. http://dx.doi.org/10.1590/S0006-87052008000200019

EBELING, A. G.; ANJOS, L. H. C.; PEREZ, D. V.; PEREIRA, M. G. \& GOMES, F. W. F. Atributos químicos, carbono orgânico e substâncias húmicas em Organossolos Háplicos de várias regiões do Brasil. Revista Brasileira de Ciência do Solo, Viçosa, v. 35, n. 2, p. 325-336, 2011.

EMBRAPA - Embrapa Informação Tecnológica. Manual de métodos de análise de solo. First ed. Brasília, Embrapa Informação Tecnológica, 1997, p. 212.

EMBRAPA - Embrapa Informação Tecnológica. Sistema Brasileiro de Classificação de Solos. 3rd ed. Brasília, Embrapa Informação Tecnológica, 2013, p. 353.

FONTANA, A., PEREIRA, M. G., ANJOS, L. H. C., BENITES, M. B. Distribution of organic carbon in the humic fractions of diagnostic horizons from Brazilian soils. Communication in Soil Science Plant and Analysis, New York v. 39, n. 4, p. 951-971, 2008. http://dx.doi.org/10.1080/00103620801925323

GANG, L. U.; SAKAGAMI, K.; TANAKA, H.; HAMADA, R. Role of soil organic matter stabilization of water-stable aggregates in soils under different types of land use. Soil Science Plant Nutrition, Hongou, v. 44, n. 2, p. 147-155, 1998.

GIACOMINI, S. J. AITA, C. \& MIOLA, E. C. C. Mineralização do carbono da palha de aveia e dejetos de suínos aplicados na superfície ou incorporados ao solo. Revista Brasileira de Ciência do Solo, Viçosa, v. 32, n. especial, p. 2661-2668, 2008.

IPCC (Intergovernmental Panel on Climate Change). HOUGHTON J. T., MEIRA FILHO L. G., LIM B., TREANTON K., MAMATY I., BONDUKI Y., GRIGGS D. J. AND CALLANDER B. A. (Eds). Revised 1996 IPCC, In: Guidelines for National Greenhouse Inventories. IPCC/OECD/IEA, Paris, France, 1997. 
IPCC, Climate Change 2007: The Physical Science Basis, Contribution of Working Group I to the Fourth Assessment Report of the Intergovernmental Panel on Climate Change. In: SOLOMON S., QIN D., MANNING M., CHEN Z., MARQUIS M., AVERYT K.B., TIGNOR M., MILLER H. L. (Eds.), Cambridge University Press, Cambridge, United Kingdom and New York, USA, 2007.

JANTALIA, C. P., ZOTARELLI, L., SANTOS, H. P., TORRES, E., URQUIAGA, S., BODDEY, R. M., ALVES, B. J. R. Em busca da mitigação da produção de óxido nitroso em sistemas agrícolas: avaliação de práticas usadas na produção de grãos do sul do país. In: ALVES, B.J.R., URQUIAGA, S., AITA, C., BODDEY, R. M., JANTALIA, C. P., CAMARGO, F. A. O., (Eds.), Manejo dos sistemas agrícolas: impacto no sequestro de $\mathrm{C}$ e N nas emissões de gases de efeito estufa. Porto Alegre: Genesis, 2006. 81-108p.

KÄMPF, N., SCHNEIDER, P. Caracterização de solos orgânicos do Rio Grande do Sul: Propriedades morfológicas e físicas como subsídios à classificação. Revista Brasileira de Ciência do Solo, Viçosa, v. 13, n. 1, p. 227-236, 1989.

KONONOVA, M. M. Soil organic matter. Its nature, its role in soil formation and in soilfertility. Pergamon, Oxford, second edition, 1966. 544p.

MELO, F. V., SCHAEFER, C. E. G. R., UCHÔA, S. C. P. Indian land use in the Raposa-Serra do sol reserve, Roraima, Amazonia, Brazil: Physical and chemical attributes of a soil catena developed from mafic rocks under Shifting cultivation. Catena, Amsterdam, v. 80, n. 2, p. 95-105, 2010.

MOURA, L N. de A., LACERDA, M. P. C., RAMOS, M. L. G. Qualidade de Organossolo sob diferentes usos antrópicos em áreas de preservação permanente no Distrito Federal. Revista Brasileira de Engenharia Agrícola e Ambiental, Campina Grande, v. 17, n. 1, p. 33-39, 2013. http://dx.doi.org/10.1590/S141543662013000100005

NOGUEIRA, E. D., TÍNEL, C. JR. J. I., VASCONCELLOS, B. M. C. Atributos químicos do solo sob diferentes coberturas vegetais em áreas do platô de Neópolis-SE. Scientia Plena, Sergipe, v. 8, n. 4, p. 1-5, 2012.

ORLOV, R. Humic acids of soils. Washington: The National Science Foundation, 1985. 378 p.

PP SYSTEMS, EGM-4 Environmental Gas Monitor For $\mathbf{C O}_{2}$ Operator's Manual Version 4.11.http:/webh01.ua.ac.be/pleco/TECH/MANUALS/PPS/EGM4/EGM4_Operation_V411.pdf, Massachusetts, USA. (consulted on 09.02.2010).

SILVA, E. B., SILVA, A. C., GRAZZIOTTI, P. H., FARNEZI, M. M. M., FERREIRA, C. A., COSTA, H. A. O., HORAK, I. Comparação de métodos para estimar a acidez potencial mediante determinação do pH SMP em Organossolos da Serra do Espinhaço Meridional. Revista Brasileira de Ciência do Solo Viçosa, v. 32, n. 5, p. 2007-2013, 2007. http://dx.doi.org/10.1590/S0100-06832008000500022

SILVA, A. C.; HORÁK, I.; TORRADO, P. C.; CORTIZAS, A. M.; RACEDO, J. R. \& CAMPOS, J. R. R. Turfeiras da serra do espinhaço meridional - MG. II - Influência da drenagem na composição elementar e substâncias húmicas. Revista Brasileira de Ciência do Solo, Viçosa, v. 33, n. 5, p. 1399-1408, 2009.

SIX, J., FELLER, C., DENEF, K., OGLE, S.M., SÁ, J. C. M., ALBRECHT, A. Soil carbon matter, biota and aggregation in temperate and tropical soils: Effects of no-tillage. Agronomie, França, v. 22, n. 7-8, p. 755-775, 2002.

SMITH J. L., MYUNG, H. U. Rapid procedures for preparing soil and $\mathrm{KCl}$ extracts for ${ }^{15} \mathrm{~N}$ analysis. Communications in Soil Science and Plant Analysis, Missouri, v. 21, n. 1, p. 2273-2279, 1990.

TAN, K. H. Humic Matter in Soil and the Environment Principles and Controversies. New York: Marcel Dekker, Inc., 2003. 398 p. http://dx.doi.org/10.1201/9780203912546 
TEDESCO, M. J., GIANELLO, C., BISSANI, C. A., BOHNEN, H., VOLKWEISS, S. J. Análises de solo, plantas e outros materiais. Rio Grande do Sul, 1995. 174p.

VALLADARES, G. S., PEREIRA, M. G., ANJOS, L. H. C., BENITES, V. M., Adierson Gilvani EBELING, A. G.; MOUTA, R. O. Humic Substance Fractions and Attributes of Histosols and Related High-OrganicMatter Soils from Brazil. Communications in Soil Science and Plant Analysis, New York 38, n. 2, p. $763-$ 777, 2007. http://dx.doi.org/10.1080/00103620701220759

VAN DEN BRINK, P. J., TER BRAAK, C. J. F. Principal response curves: analysis of timedependent multivariate responses of biological community to stress. Environmental Toxicology and Chemistry, Hoboken, v. 18, n. 2, p. 138-148, 1999. http://dx.doi.org/10.1002/etc.5620180207

YAO, Z., ZHENG, X., DONG, H., WANG, R., MEI, B., ZHU, J. A 3-year record of $\mathrm{N}_{2} \mathrm{O}$ and $\mathrm{CH}_{4}$ emissions from a sandy loam paddy during rice seasons as affected by different nitrogen application rates. Agriculture, Ecosystems and Environment, Amsterdam, v. 152, p. 1-9, 1012.

YOODER, R. E. A direct method of aggregate analysis of soils and a study of the physical nature of erosion losses. Journal of America Society Agronomy, Madison, v. 28, p. 337-351, 1936.

http://dx.doi.org/10.2134/agronj1936.00021962002800050001x 